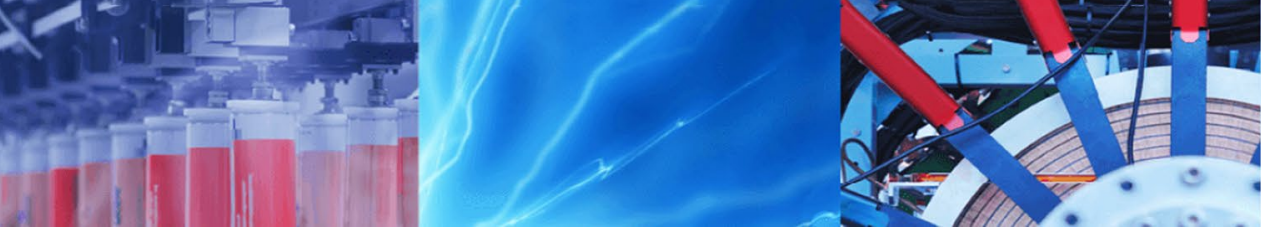

Research Article

\title{
A case study on mineralogy and physico-mechanical properties of commercial bricks produced in Nepal
}

\author{
Yagya Prasad Chapagain ${ }^{1}$ - Sanjeev Sapkota ${ }^{1}$. Dol Bahadur Ghale ${ }^{1} \cdot$ Narendra Bahadur Bohara $^{1} \cdot$ Nirjan Duwal $^{2}$. \\ Jagadeesh Bhattarai ${ }^{1}$ (i)
}

Received: 19 June 2020 / Accepted: 16 September 2020 / Published online: 21 October 2020

(c) Springer Nature Switzerland AG 2020

\begin{abstract}
Uses of clay brick have practiced since ancient times in the Kathmandu valley of Nepal as structural materials for the construction of historical monuments, temples, and even modern buildings so on. However, their durability and sustainability properties are less studied scientifically in Nepal. Taking into consideration, analysis of mineralogical phases and physico-mechanical properties of modern clay bricks of Nepal was carried out using X-ray powder diffraction as well as Fourier transform infra-red techniques, and American Standards for Testing Materials standards, respectively. Quartz, feldspars, alumina-rich spinel, muscovite, primary mullite, and hematite are constituent in the bricks. Appearance of the spinel and primary mullite phases in burnt brick samples with diminishing feldspar peaks were to be different, indicating that the temperature applied for the making of these clay bricks presumed to be between 900 and $1050^{\circ} \mathrm{C}$. All the commercially used contemporary brick samples analyzed herein could be of II and III classes based on the estimated physical and mechanical properties. They showed the water absorption capacity $\left(W_{A C}\right)$, apparent porosity $\left(P_{A}\right)$, bulk density $\left(D_{B}\right)$, and compressive strength $\left(\mathrm{S}_{C}\right)$ in the range of $5-30 \%, 10-40 \%, 1.1-2.15 \mathrm{~g} / \mathrm{cm}^{3}$, and $3.35-10.53 \mathrm{MPa}$, respectively, and these properties have a reasonable correlation. The $S_{C}$ is to be decreased exponentially with increasing both the $W_{A C}$ and $P_{A}$ and increased exponentially with $D_{B}$.
\end{abstract}

Keywords Bricks · Mineralogical composition · Durability · Water absorptivity · Density · Compressive strength

\section{Introduction}

In the modern era, clay bricks widely use as one of the structural materials and it used since the Mesopotamian, Egyptian, and Roman periods [1], existing as archaeological structural elements. The extensive uses of the contemporary bricks are mainly due to the availability of its raw clay materials world widely. What is more, the quality and durability assessments of different clay bricks principally based on their essential mineralogical phase, physico-sintering, and mechanical properties. It said that the best quality of the ceramic bodies also depends on the uses of clay types [2-4], and firing temperature [5-8] and conditions $[9,10]$ during their production time because these parameters are critical factors to modulate different physico-mechanical properties of the ceramic bodies. A series of mineralogical phase transformation occurs during the firing of natural clay materials $[11,12]$. The $\mathrm{Al}_{2} \mathrm{O}_{3}$ and $\mathrm{SiO}_{2}$, which vary with clay types, are responsible for the refractoriness, shrinkage, and plasticity properties of clay bricks [13] The main mineralogical compositions of $\mathrm{Al}_{2} \mathrm{O}_{3}$ and $\mathrm{SiO}_{2}$, which vary with clay types, of the raw materials for the fired-clay brick production are responsible for their refractoriness, shrinkage, and plasticity properties [13]. An increase of $\mathrm{Al}_{2} \mathrm{O}_{3}$ content mostly impacts on increasing the refractoriness and mechanical strength of the clay bricks

Jagadeesh Bhattarai, bhattarai_05@yahoo.com; jagadeesh.bhattarai@cdc.tu.edu.np| ${ }^{1}$ Central Department of Chemistry, Tribhuvan University, Kirtipur, Kathmandu, Nepal. ${ }^{2}$ Department of Chemistry, St. Xavier's College, Thapathali, Kathmandu, Nepal.

SN Applied Sciences (2020) 2:1856 | https://doi.org/10.1007/s42452-020-03535-y 
[14]. Similarly, $\mathrm{SiO}_{2}$ affects a decrease of shrinkage and refractoriness of the ceramic bodies [15].

On the other hand, varieties of feldspars and oxides of sodium, potassium, calcium, magnesium, iron as well titanium are reliable fluxing components, which decrease the viscosity of the liquid phase of the clay brick products [16]. It believes that the presence of low-melting fluxing oxides in clay minerals play significant roles in the production of all types of clay bricks. The fluxing oxides (mainly of sodium and potassium oxides) react with silica and alumina of clay minerals to promote liquid phase formation that facilitates the densification process of the brick bodies at high temperatures [17]. They show a direct correlation with the physical properties of bulk density $\left(D_{B}\right)$ and an inverse relation with water absorption capacity $\left(\mathrm{W}_{A C}\right)$ or apparent porosity $\left(\mathrm{P}_{\mathrm{A}}\right)$ of the fired-clay brick bodies [18].

Recent studies are also focused for exploring the development of eco-friendly clay bricks with the addition of a small amount of agricultural wastes $[19,20]$, recycled waste marble products [21, 22], waste glass sludge [23], and fly ash $[24,25]$ so on as aggregates in the brick raw materials. These waste materials are generally to be the rich sources of $\mathrm{Al}_{2} \mathrm{O}_{3}, \mathrm{SiO}_{2}$, and fluxing oxides. The waste materials proved to be having a positive effect on the physical, chemical and mechanical strength of the clay bricks at low production cost leading to more sustainable construction and also to minimize the pollution overburden caused by their deposition in environments. These waste materials enhanced different properties of clay bricks, leading toward more economical and sustainable construction.

The mechanical properties of the fired-ceramic body decrease with increasing the porosity, pore-size, and spatial pore distribution so on [26]. The total porosity of brick samples decreases and pore-size distribution changes towards larger pore sizes as the firing temperatures rise [27]. It concluded from the previous studies that the brick specimens with high porosity and a high percentage of pores with a diameter of $<2 \mu \mathrm{m}$ underwent significant mechanical damages [28]. It reported that highly porous ceramic bodies had high water absorption capacity, low density, and tends to be less durable with less stressresistant properties [29]. The flexural strength $\left(\mathrm{S}_{\mathrm{F}}\right)$, one of the essential mechanical properties of the ceramic bodies, is accepted to be decreased exponentially with apparent porosity $\left(P_{A}\right)$ as given by the relation as; flexural strength $\left(\mathrm{S}_{\mathrm{F}}\right)=\mathrm{S}_{\mathrm{O}} \times \exp \left(-\mathrm{nP}_{\mathrm{A}}\right)$ where, $\mathrm{S}_{\mathrm{O}}$ and $\mathrm{n}$ are experimental constants [30]. The validity of this relation tested in the case of the ceramic tiles, and it claimed that the $\mathrm{S}_{\mathrm{F}}$ of ceramic tiles increases exponentially with decreasing $P_{A}$ and $W_{A C}[31$, 32]. Therefore, it expects that the low $P_{A}$ of the fired-clay bricks might also be responsible for showing their excellent physico-mechanical properties. Consequently, $\mathrm{W}_{A C}, \mathrm{P}_{\mathrm{A}^{\prime}}$
$\mathrm{D}_{\mathrm{B}}$, and $\mathrm{S}_{\mathrm{C}}$ of the clay bricks would be commonly estimated to know their various technologically essential properties.

Clay brick manufacturing is one of the ignorant of modern day improvements and innovations in Nepal, even though there is an increasing ability and desirability for purchasing contemporary bricks, especially in populated areas of our country like Kathmandu valley. Brick users are mostly concerned with their prices and less concerned with durability and sustainability. A quality assessment of the bricks depends on their mineralogical compositions, physico-sintering and mechanical properties. Although there is a lack of sufficient research works on the physico-mechanical properties of the commercial clay bricks of Nepal, ceramic tiles [33,34], archaeological samples $[35,36]$ and firing temperature effects $[37,38]$ on brick manufacturing reported in literatures. Based on laboratory scale tests, the technical feasibility of the commercial brick renders a very workable option. In this context, the current research work aimed to identify the mineralogical phases using XRPD and FTIR technique, and to estimate the physical and mechanical properties of $W_{A C}, D_{B}, P_{A}$ and $S_{C}$ of forty-nine sample specimens of seventeen varieties of the commercially available clay bricks in Nepal by different ASTM criterion.

\section{Materials and methods}

Total forty-nine specimens of seventeen types/grades of contemporary clay brick samples, produced in Kathmandu, Lalitpur, Bhaktapur, Bara and Nawalparasi districts of Nepal with local conditions, were used to carry out the current research work. Out of these forty-nine brick specimens, one specimen was of the sun-dried type, and the remaining forty-eight were of sixteen varieties of the firedclay bricks (i.e., three sample specimens of each kind of the fired-brick). Some selective brick samples were hammered and ground to make powder for XRPD and FTIR analyses to identify their mineralogical characterization.

The mineralogical characterization of some selective brick samples was carried out using XRPD analysis on a D8 Advanced Diffractometer (Bruker, Germany) with CuKa radiation $(\lambda=0.15418 \mathrm{~nm})$ at a scanning speed of $2^{\circ} / \mathrm{min}$ in $2 \theta$ mode between $10^{\circ}$ and $70^{\circ}$ in a randomly oriented way at Nepal Academy of Science and Technology (NAST), Khumaltar, Lalitpur. Major and minor phases present in the analyzed clay bricks were identified from their d-spacing values using JCPDS (Joint Committee on Powder Diffraction Standard) database files as references [39]. The spectra of the brick specimens recorded for qualitative mineralogical analysis using Fourier Transform Infrared Spectrophotometer A217053 available at NAST, Lalitpur. 
Three sample specimens of each type/grade of the collected sixteen types of the modern fired-clay bricks except the sun-dried sample examined for their physical and mechanical properties. Three different physical properties (i.e., $W_{A C}, D_{B}$, and $P_{A}$ ) of all the fired-clay brick sample specimens were estimated by using the following Eqs. (1), (2) and (3) according to ASTM criteria [40] that require boiling process. A minimum of three specimens each brick sample were considered for at least triplicate testing to establish the reliability of these properties results.

$\mathrm{W}_{\mathrm{AC}}(\%)=\frac{\mathrm{W}_{\text {sat }}-\mathrm{W}_{\text {dry }}}{\mathrm{W}_{\mathrm{dry}}} \times 100$

$P_{A}(\%)=\frac{W_{\text {sat }}-W_{\text {dry }}}{V_{\text {bul }}} \times 100$

$D_{B}\left(g / \mathrm{cm}^{3}\right)=\frac{W_{\text {dry }}}{V_{\text {bul }}}$

where $W_{\text {dry }}$ is dry weight in gram, $W_{\text {sat }}$ is saturated weight in gram, and $V_{\text {bul }}$ is the volume of outer sides in $\mathrm{cm}^{3}$ of the modern clay brick specimens.

The compressive strength $\left(S_{C}\right)$ of the clay brick specimens was estimated using RAM DIA 222-2 mm with a maximum load of $2000 \mathrm{kN}$ compression testing machine (CTM) available at Central Material Testing Laboratory, Department of Civil Engineering of Pulchowk Engineering Campus, Tribhuvan University, Lalitpur using Eq. (4) following ASTM criteria [41].

$\mathrm{S}_{\mathrm{C}}(\mathrm{MPa})=\frac{\text { Maximum load at failure }(\mathrm{N})}{\text { Area of bed face }\left(\mathrm{mm}^{2}\right)}$

The clay brick sample specimens were immersed in distilled water at room temperature for $24 \mathrm{~h}$ and then the brick specimens were removed for the $S_{C}$ test. The surplus water of the brick surface was drained out using a moistened smooth cloth at room temperature before carrying the $S_{C}$ test. The unevenness observed was also removed for the flat parallel faces. The capping was subjected to the CTM to estimate the $S_{C}$ of all the analyzed clay brick samples which were not sufficiently flat surfaces.

\section{Results and discussion}

\subsection{Mineralogical analysis}

The mineralogical analysis accomplished by XRPD and FTIR techniques, and the results are shown in Figs. 1 and 2, respectively. Quartz, feldspars, hematite, alumina-rich spinel, muscovite type mica are identified in all brick samples, whereas, primary mullite phase is observed in some brick samples from XRPD analysis, as depicted in Fig. 1. The clay brick CAB- 5 shows the XRPD peaks for quartz, feldspars, spinel, and hematite with primary mullite phase, which produced using raw clay materials of the RCB-4 sample, as shown in Fig. 1a. The muscovite phase with quartz, feldspars and hematite are observed in the RCB-4, and the mullite phase did not observed for other brick samples except CAB-5. Again, the muscovite with significant amounts of quartz, feldspars, spinel, and hematite are observed in XRPD patterns of the fired-brick CCB-7 and BSB-11, as depicted in Fig. 1b, although the NTB-17 does not show the muscovite. This fact reflects that the firing temperature for the production of these fired-clay bricks should not be the same. Consequently, it can presume that the CAB- 5 brick should produce at a higher firing temperature than other fired-brick samples used in this study.

It is substantive to cite here that aluminum-rich spinel and primary mullite phases were reported to develop between $900-1000{ }^{\circ} \mathrm{C}$ and $1000-1100^{\circ} \mathrm{C}$ firing temperature, respectively, while the spinel phase was diminished by forming a well-shaped mullite crystals at $1200^{\circ} \mathrm{C}$ or high temperatures $[42,43]$. However, four fired-clay brick samples analyzed here, except the sun-dried RCB-4 and CAB-5, did not develop even the primary mullite phase. Furthermore, the muscovite phase is observed in XRPD patterns of the fired CCB-7 and BSB-11, as depicted in Fig. 1 b. Consequently, it can say that the analyzed four contemporary fired-clay bricks, except the CAB-6 sample, should be manufactured at two firing temperature ranges, i.e., $<900^{\circ} \mathrm{C}$ and $900-1000^{\circ} \mathrm{C}$. The CAB-5 brick sample to be fired at $1000-1100^{\circ} \mathrm{C}$ during its production in brick kiln.

FTIR spectra of the powder form of the fired-clay bricks taken to identify the functional groups present in them. As shown in Fig. 2a, the FTIR absorption peaks at 3701 and $3623 \mathrm{~cm}^{-1}$ corresponding to oxygen-hydrogen bond are seen only for the clay raw materials (i.e., RCB4), which use for the production of fired-brick samples of CAB-5 and CBB-6. The FTIR peak in these two absorption regions is mostly due to the stretching vibrations of the hydrogen-bonded water molecule of different clay minerals. It reported that inner hydroxyl groups, lying between the tetrahedral and octahedral sheets of the clay minerals gave an absorption peak near $3620 \mathrm{~cm}^{-1}$ and a peak near $3700 \mathrm{~cm}^{-1}$ relates to the in-phase symmetric stretching vibration $[44,45]$.

A broad absorption peak at about $3460-3435 \mathrm{~cm}^{-1}$ is observed for the fired-bricks of DKB-2, RCB-4, CBB- 6 , and BHB-10, except CAB-5 and CDB-8 (Fig. 2), which assigned to $\mathrm{OH}$ stretching vibration of hydroxide in the brick sample [46]. This absorption band region is accompanied by a small absorption band at $1626 \mathrm{~cm}^{-1}$ assigned to $\mathrm{O}-\mathrm{H}$ bending [47]. However, the absorption bands in these 
Fig. 1 XRPD patterns of the mineralogical phases present the brick samples of Kathmandu valley
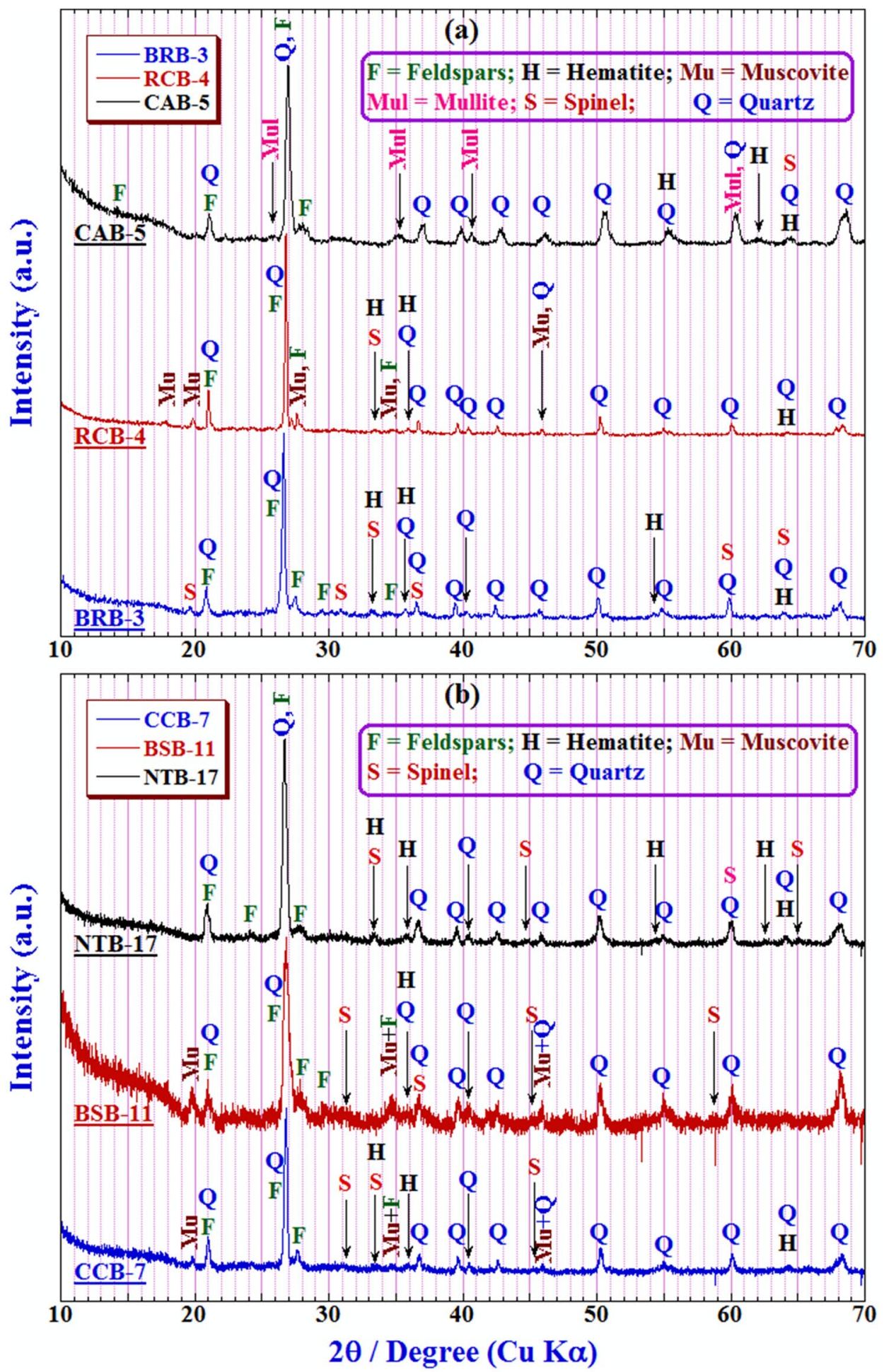

two wavelength regions for fired-clay bricks of $C A B-5$ and CDB-8 are nearly diminished, because the broadening of the FTIR spectra of the brick samples should generally be affected by firing temperature employed during their production and hence it can be assumed that the firing temperature used to produce the brick samples of DKB-2,
RCB-4, CBB- 6 and BHB- 10 should be lowered than that of CAB-5 and CDB-8 samples. The absorption peaks at 2359 and $2327 \mathrm{~cm}^{-1}$ should be affected by the measurement condition error, probably due to the room $\mathrm{CO}_{2}$ gas. A similar result was also reported in previous work on the bentonite clay mineral [48]. 

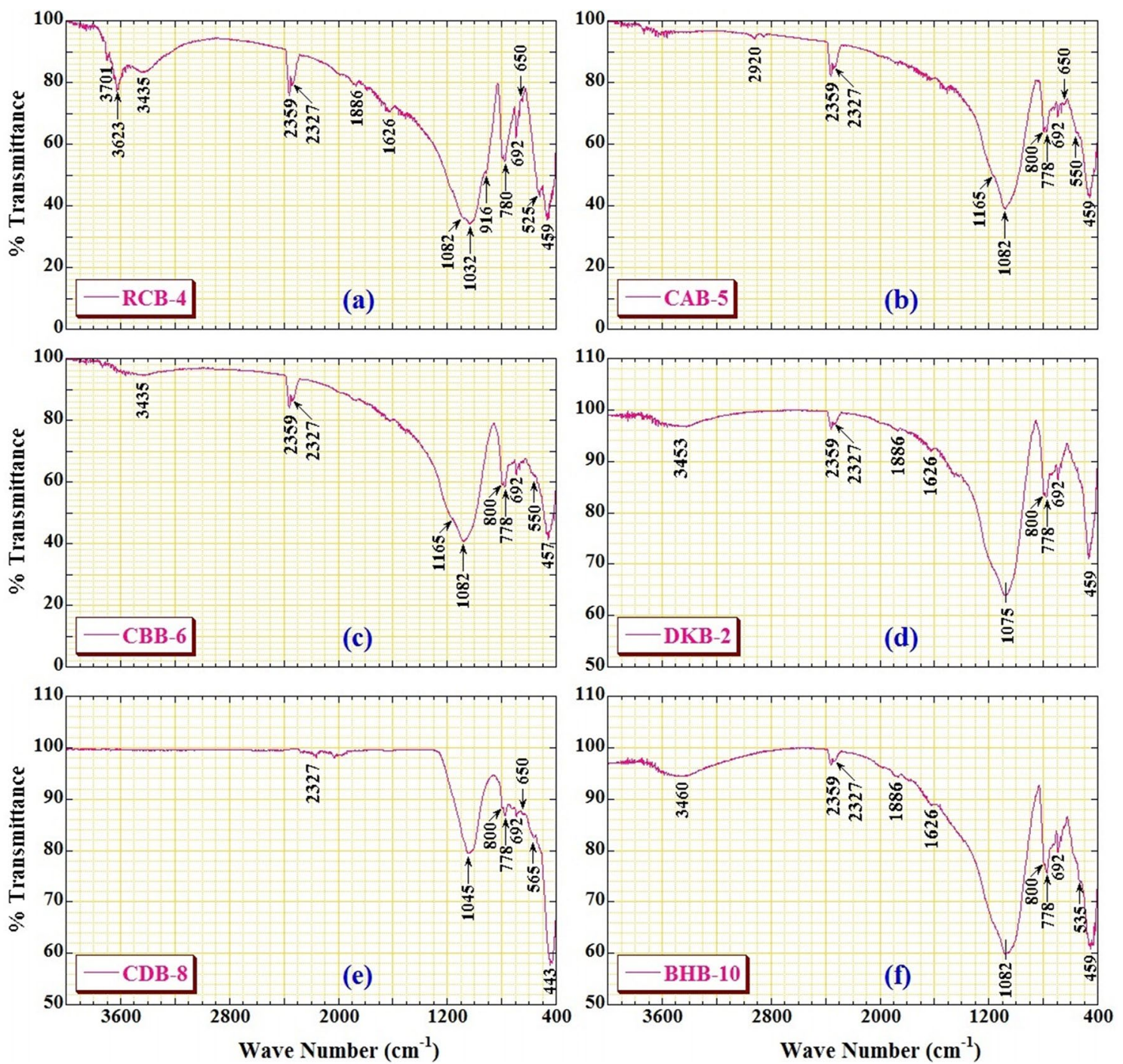

Fig. 2 FTIR spectra of the brick samples of Kathmandu valley

The presence of a strong absorption band in the range of $1082-1045 \mathrm{~cm}^{-1}$ for all the measured fired-clay brick samples indicates the presence of silica ( $\mathrm{Si}-\mathrm{O}$ stretching) except sun-dried brick samples. The sun-dried brick sample, i.e., RCB-4 (Fig. 2a) shows a peak at $1032 \mathrm{~cm}^{-1}$ attributed to the $\mathrm{Si}-\mathrm{O}$ stretching vibration and a band at $525 \mathrm{~cm}^{-1}$ assigned to $\mathrm{Si}-\mathrm{O}-\mathrm{Al}$ (octahedral Al) bending vibration. On the other hand, a small peak at $916 \mathrm{~cm}^{-1}$ for the RCB-4 sample (Fig. 2a) is mostly by the contribution to bending of $\mathrm{OH}$ linked to $\mathrm{Al}^{3+}$ of the alumino-silicates clay minerals [49] which is found to be disappeared for all the analyzed fired-brick samples, mostly due to diminishing of octahedral cations upon firing at high temperature.

The quartz contains in all the analyzed fired-brick samples used in this study can be confirmed from the FTIR peaks at $800,778,692$, and $443-459 \mathrm{~cm}^{-1}$. Among these FTIR peaks, around $778 \mathrm{~cm}^{-1}$ was reported to be more suitable for the quantitative analysis of quartz in ceramic bodies like brick or tiles [50]. Besides, the absorption peak around $775-780 \mathrm{~cm}^{-1}$ can be assigned for Si-O-Al compounded vibrations of feldspars [51]. Besides, weak FTIR band in the range of $565-525 \mathrm{~cm}^{-1}$ in all fired-brick samples of Kathmandu Valley (Nepal) contain trace amounts of hematite. The similar result of the FTIR absorption peak at $540-550 \mathrm{~cm}^{-1}$ due to the presence of small amounts of hematite in the archeological ceramic bodies used in the archeological buildings of Kathmandu valley was also previously reported [35]. The results univocally show quartz as the prominent compound of the commercially available fired clay bricks in Kathmandu valley. 


\subsection{Physico-mechanical properties of clay brick}

An optimum combination of raw clay minerals and other admixtures is considered as one of the crucial steps for the production of good quality clay bricks because the physico-mechanical properties of such structural materials depend on the optimum conditions maintained at the time of manufacturing. The physico-mineralogical properties of the contemporary brick samples are considered in this study to have the benefit of their mechanical strength and durability.

Figure 3 shows the result of the average $\mathrm{W}_{\mathrm{AC}}$ of all the brick sample specimens collected from the Kathmandu Valley of Nepal. It noticed that most of the analyzed firedclay brick samples show $10-30 \% \mathrm{~W}_{\mathrm{AC}}$, except five brick samples (i.e., DKB-2, CBB-6, CCB-7, CDB-8, BSB-11) which show less than $10 \% \mathrm{~W}_{A C}$ (Fig. 3). It is significant to note here that brick samples DKB- 2 and BRB-3 are used for the renovation of old archaeological/historical monuments/ temples of Kathmandu valley which were destroyed during the Great Gorkha earthquake in April 2015. The $\mathrm{W}_{\mathrm{AC}}$ value of bricks is generally found to be slightly higher than that of ceramic tiles [33].

On the other hand, the brick samples $C A B-5, C B B-6$, CCB-7, CDB-8, and CJB-9 are locally called as "Chinese brick" usually used for decorative wall structures, while the remaining brick samples used in this study are of locally produced fired-bricks collected from Kathmandu Valley including Bara and Nawalparasi districts of Nepal. The technique and clay raw materials used for produce the first seven types of the bricks from DKB-2 to CJB-9, except one sun-dried brick sample, as shown in Fig. 3 , is slightly different than of the remaining ten types of brick samples. Consequently, it can expect that those brick samples used for renovation of archaeological/historical and decorative brick structure should have high durability with good mechanical strengths than those of local clay brick samples having more than $15 \% \mathrm{~W}_{\mathrm{AC}}$. A low amount of the $W_{A C}$ is desirable at all times for the production of good quality fired-clay bricks. Similar high $\mathrm{W}_{\mathrm{AC}}$, i.e. $10-30 \%$ was reported antecedently in fine-grained soils that were found to be related to the raw clay content and also was reported that the water absorption less than $10 \%$ in brick samples should be a satisfactory indicator of the durability of earthen blocks construction purposes [52]. Besides the estimated $\mathrm{P}_{\mathrm{A}}$ of all the brick samples used to study is found to be decreased with decreasing the $\mathrm{W}_{\mathrm{AC}}$, and its value is found in between 10 and 40\%, as shown in Fig. 4.

The estimated $D_{B}$ values of all fired-brick sample specimens except sample RCB-4, as shown in Fig. 5 . It is clear from the figure that six types of the clay brick sample specimens, i.e., BHB-10, GMB-12, KMB-13, STB-14,
Fig. 3 Water holding capacity of the analyzed clay brick samples

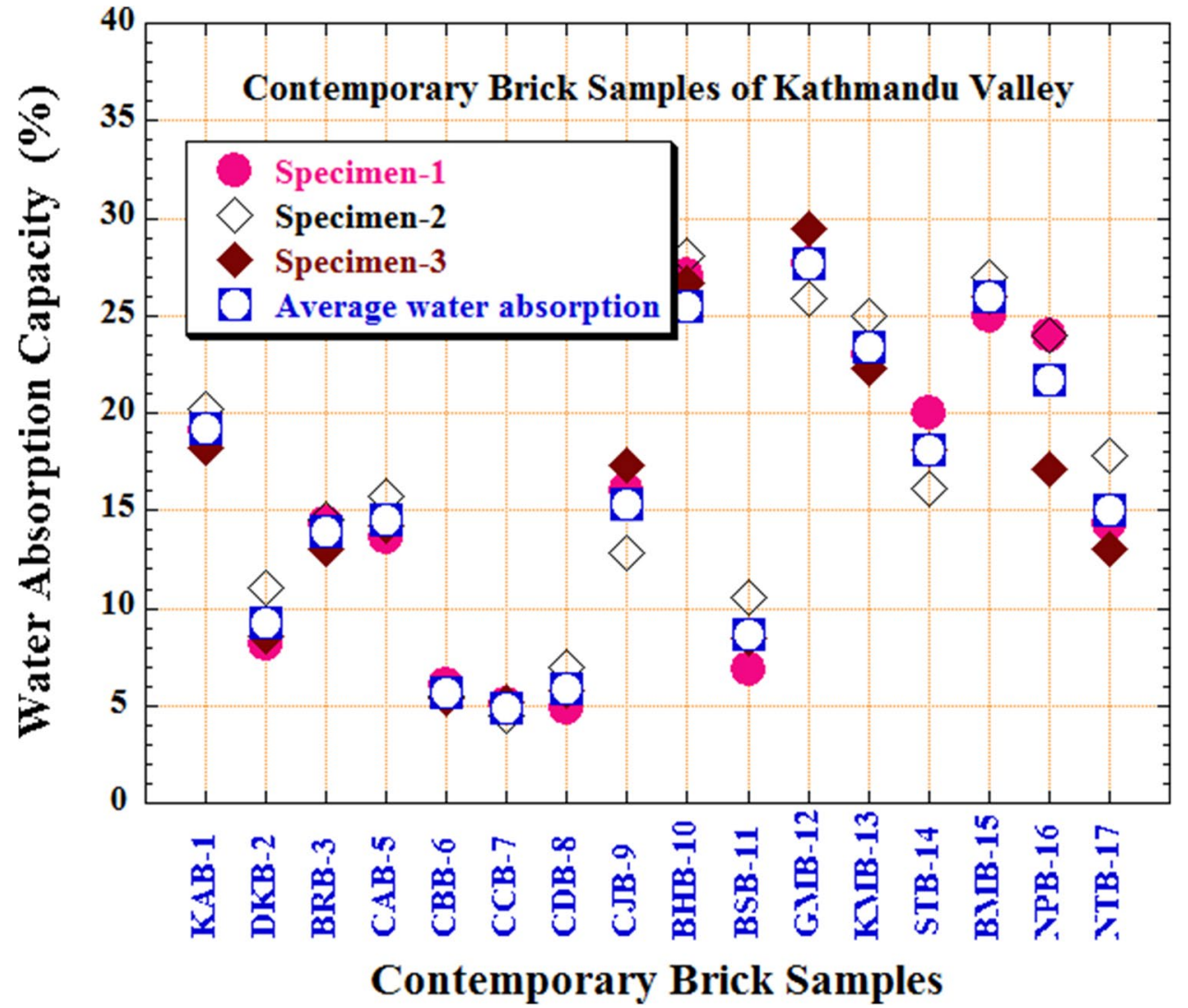


Fig. 4 Apparent porosity of the analyzed clay brick samples

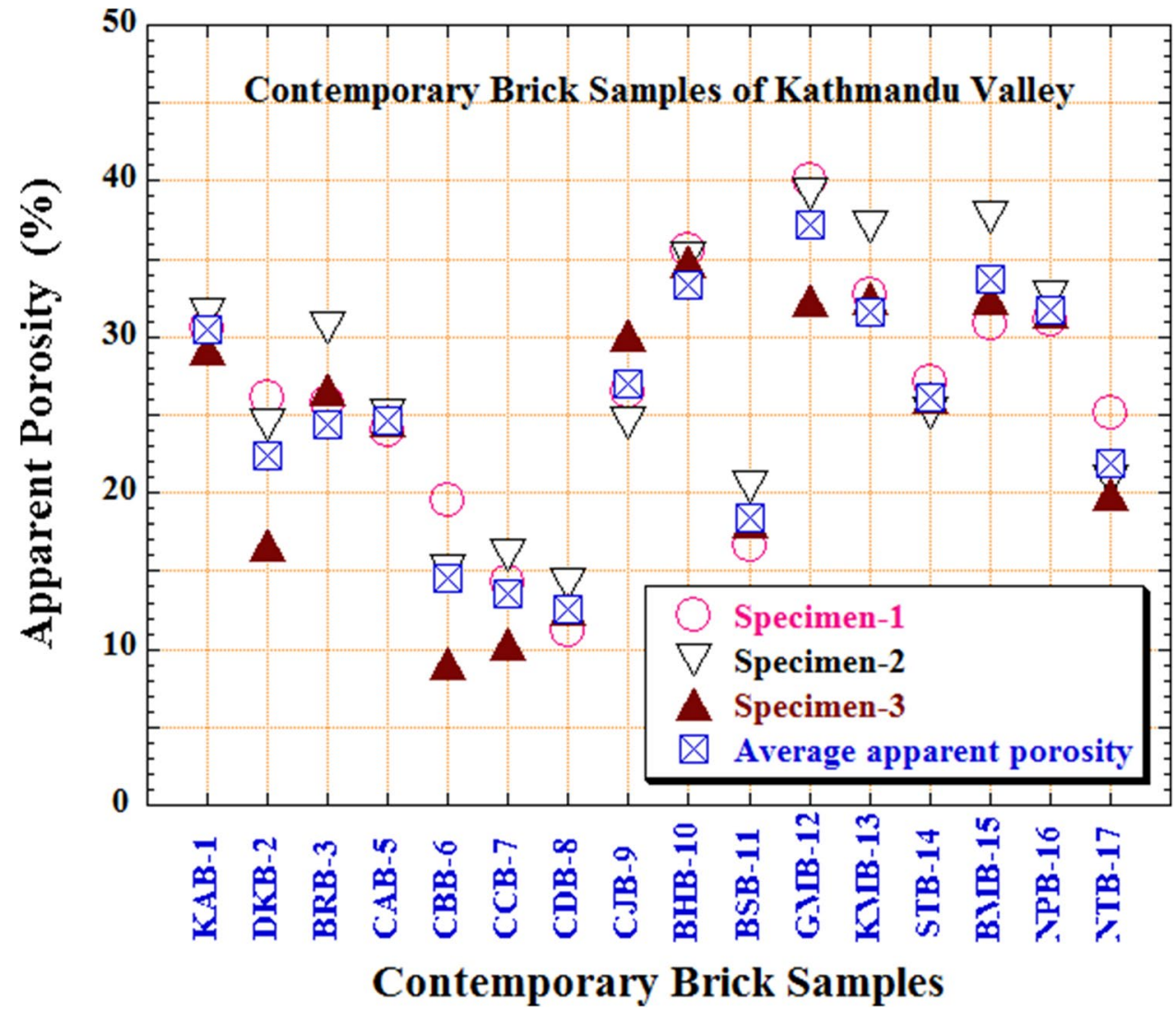

Fig. 5 Bulk density of the analyzed clay brick samples

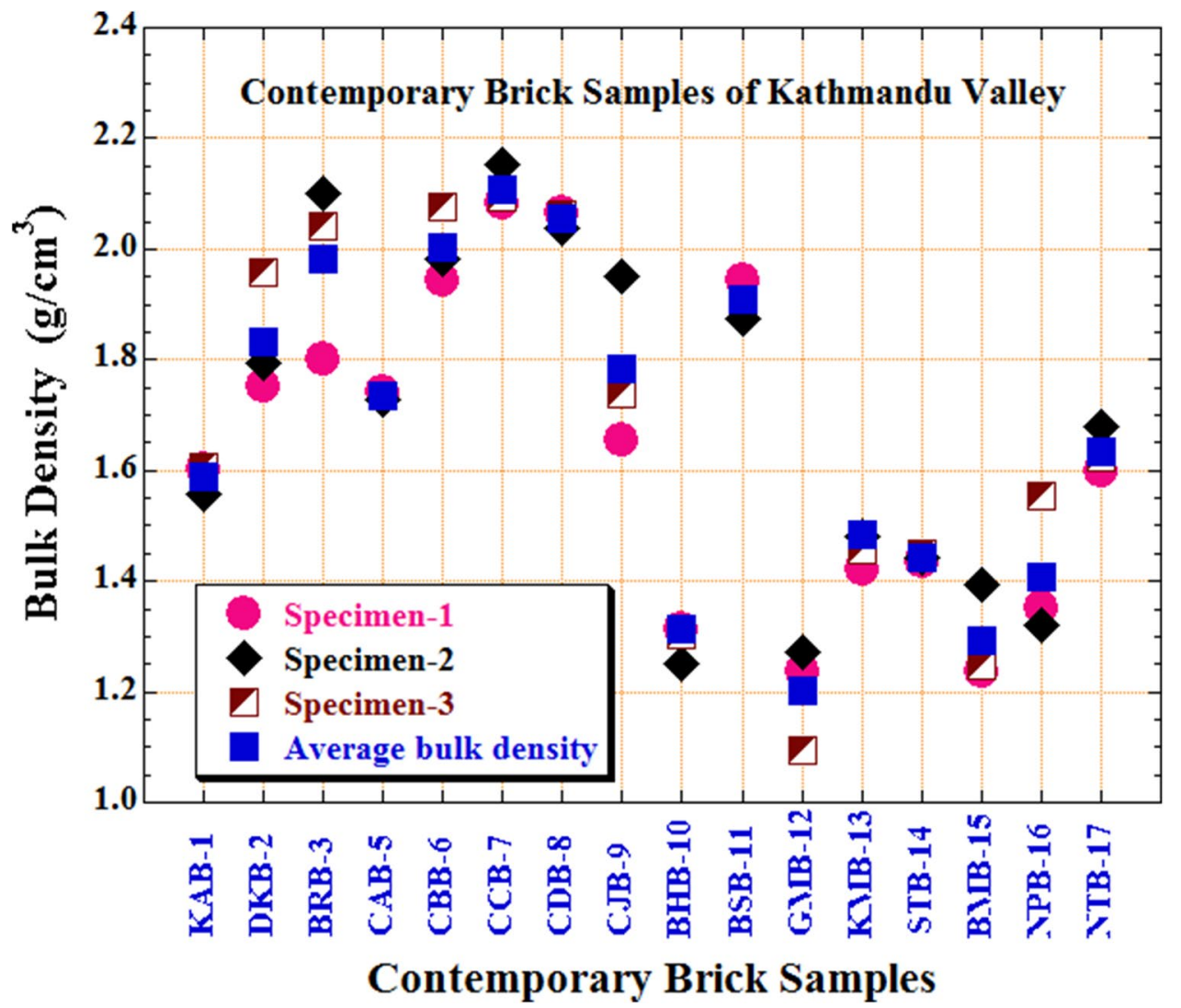

SN Applied Sciences 
BMB-15, and the NPB-16 shows the $D_{B}$ less than $1.5 \mathrm{~g} /$ $\mathrm{cm}^{3}$, while it found between 1.5 and $2.2 \mathrm{~g} / \mathrm{cm}^{3}$ in remaining ten types of the fired-brick sample specimens. Low $D_{B}$ value observed for the brick specimens is directly related to high porosity and low particle packing, and this low density of the brick samples demonstrates useful applications as lightweight construction materials. The estimated $B_{D}$ values of these bricks are suggestive of a low packing density and poor contact among particles. Previous studies also reported the possibilities of the improvement of any fired-bricks' packing density could do by lowering of the molding moisture content (for instance, the optimum moisture content) in the brick soils [53].

As a result, it obtained the expected results that the average $P_{A}$ of all fired-clay bricks decreased with increasing their average $D_{B}$, as depicted in Fig. 6 , which also shows a clear relationship between the average $D_{B}$ and average $W_{A C}$ for all sixteen types of contemporary fired-clay brick samples. Both the $\mathrm{W}_{A C}$ and $\mathrm{P}_{\mathrm{A}}$ were found to be decreased by increasing the $D_{B}$ bulk density. These results are mostly supported by the fact that the low-density value observed for the fired-brick samples is directly related to their high apparent porosity and high water absorption capacity with little particle packing. In general, it is believed that the fired-clay bricks have expected high bulk density and high compressive strength with low water absorption capacity and apparent porosity.

An approximation of different physico-mechanical characteristics of the clay brick samples plays a very crucial role in their quality control as well as durability. One of the essential mechanical parameters of the brittle ceramic bodies like clay brick is compressive strength $\left(\mathrm{S}_{\mathrm{C}}\right)$ [41]. Among sixteen fired-brick samples except one sundried brick, eleven fired-bricks have the $S_{C}$ values about 5-11 MPa other than CDB-8 sample, and the remaining five fired-bricks have less than $5 \mathrm{MPa}$ as depicted in Fig. 7 . The sun-dried RCB- 4 brick sample shows the minimum $\mathrm{S}_{C}$ of $0.54 \mathrm{MPa}$. It has a meaning to clear that both the firedclay brick samples of CAB- 5 and CBB- 6 were produced at different firing temperatures in different conditions using the same raw materials as for the sun-dried RCB-4 clay brick sample. It is anticipated on the facts that low quality and durability of the fired-clay brick samples are also related to their high water holding capacity as well as porosity and low density.

There is an effective correlation between the compressive strength $\left(S_{C}\right)$ with all these three types of physico-sintering properties (i.e., $\mathrm{W}_{\mathrm{AC}}, \mathrm{P}_{\mathrm{A}}$, and $\mathrm{D}_{\mathrm{B}}$ ) of all seventeen types of fired-clay bricks used in this study as shown in Figs. 8, 9, 10 and 11. The $S_{C}$ of the brick samples is found to be decreased exponentially with increasing
Fig. 6 Changes of apparent porosity and bulk density of the analyzed clay brick samples as a function of water absorption capacity

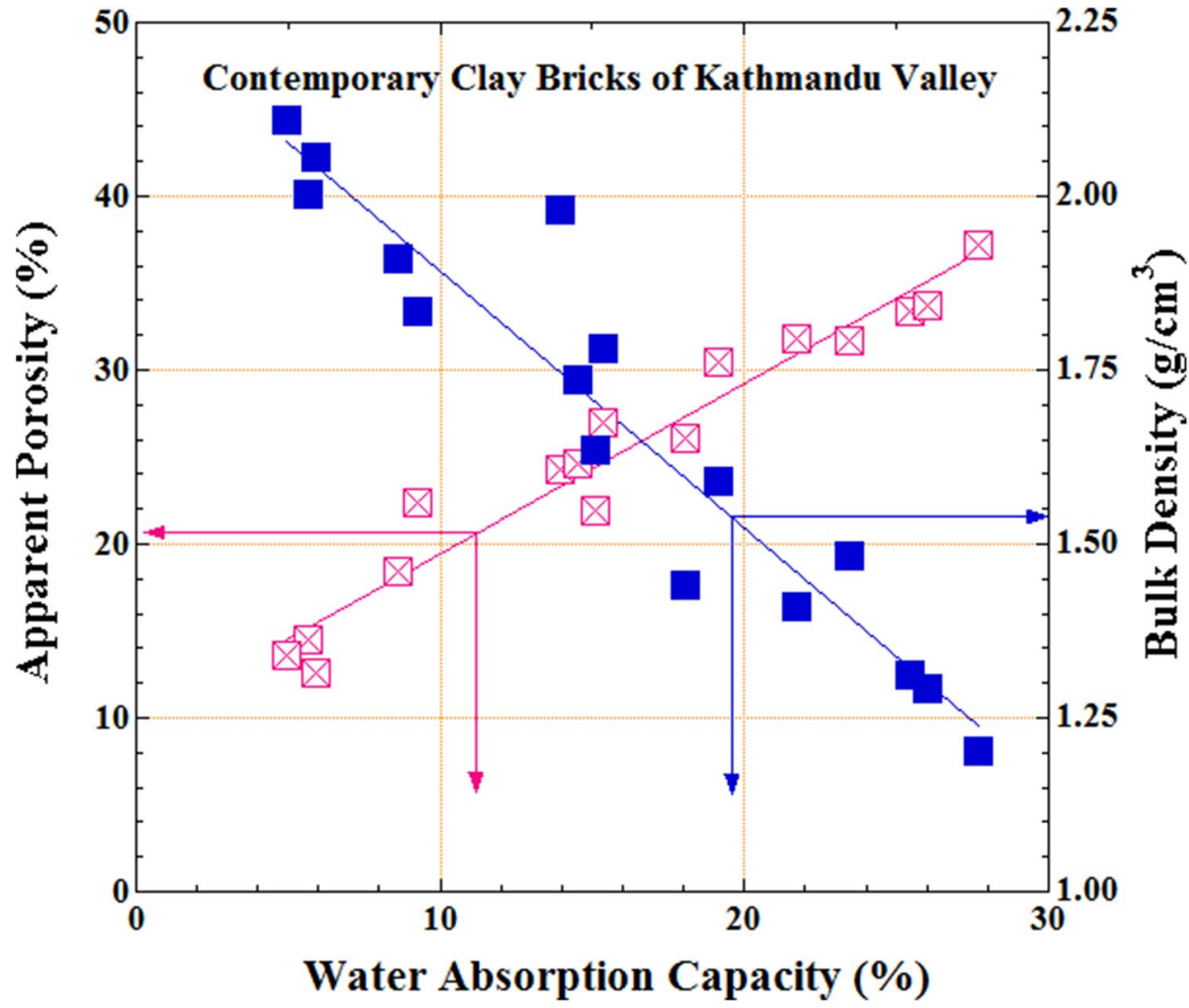


Fig. 7 Compressive strength of the analyzed clay brick samples

Fig. 8 The effect of the waterholding ability of the analyzed clay brick samples on their compressive strength
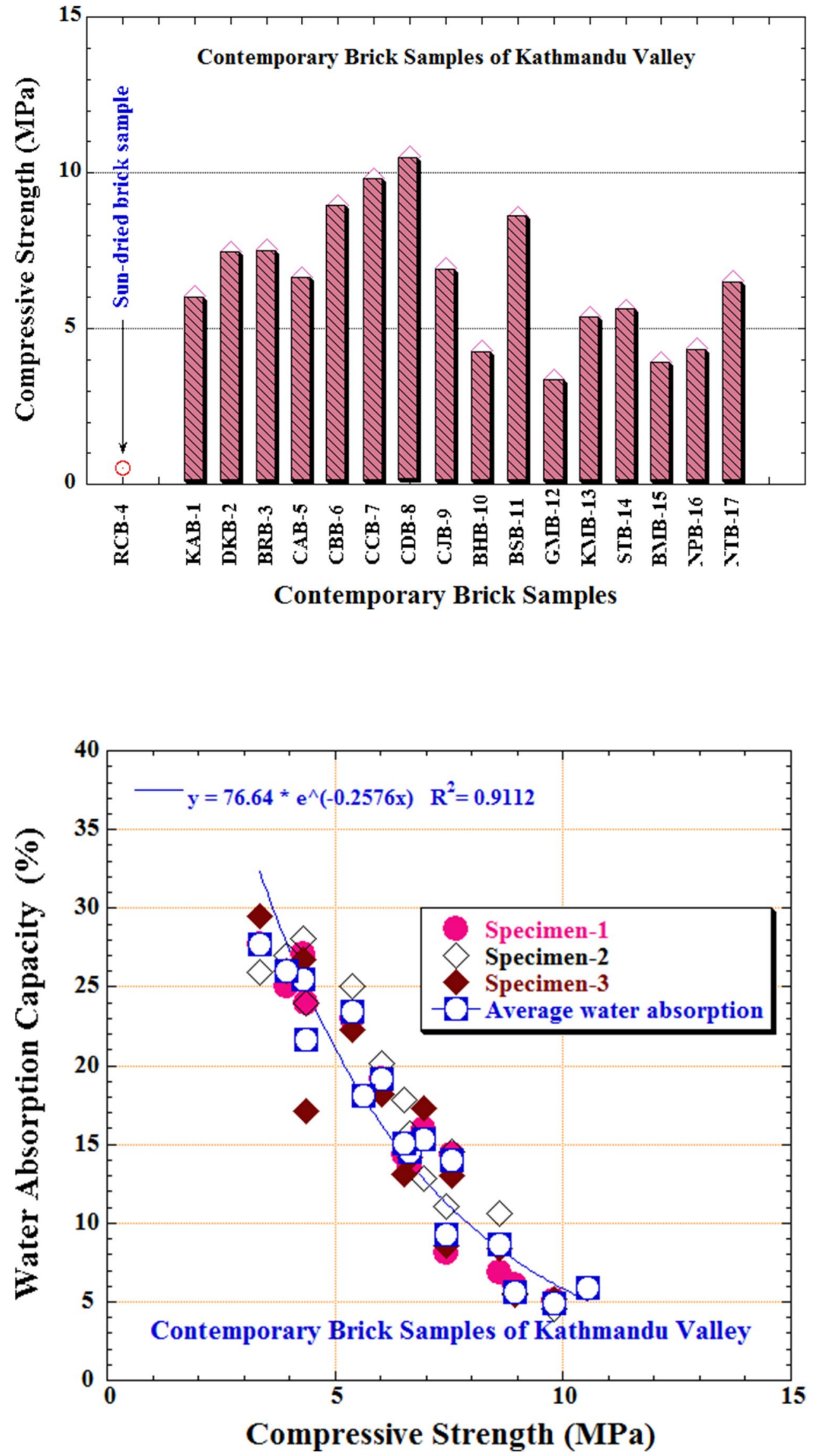

SN Applied Sciences A SPRINGER NATURE journa 
Fig. 9 The influence of the apparent porosity of the analyzed clay brick samples on their compressive strength

Fig. 10 The relation between the bulk density and compressive strength of the fired-clay bricks
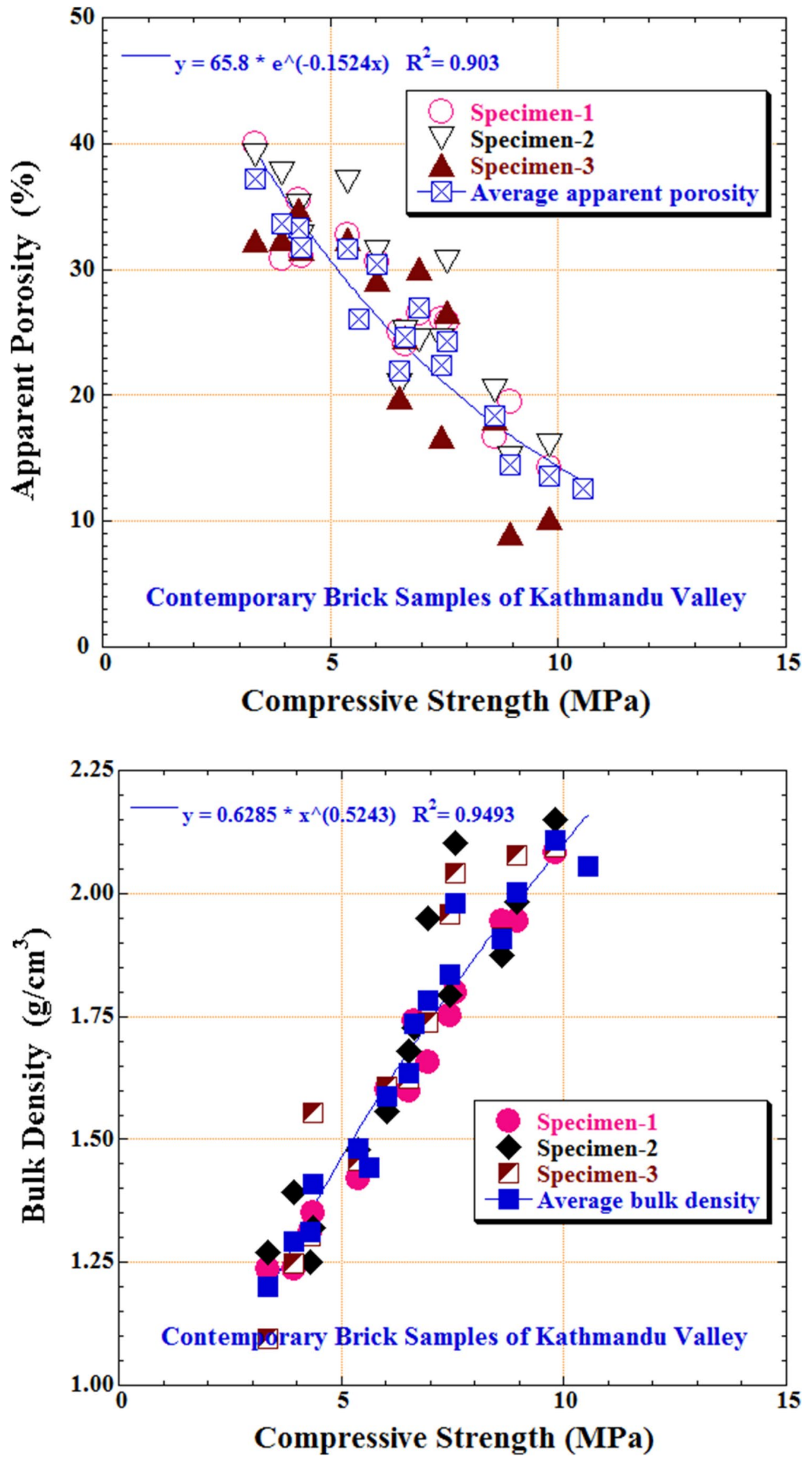
Fig. 11 Changes of water absorption, apparent porosity and bulk density of the analyzed clay brick samples as a function of compressive strength

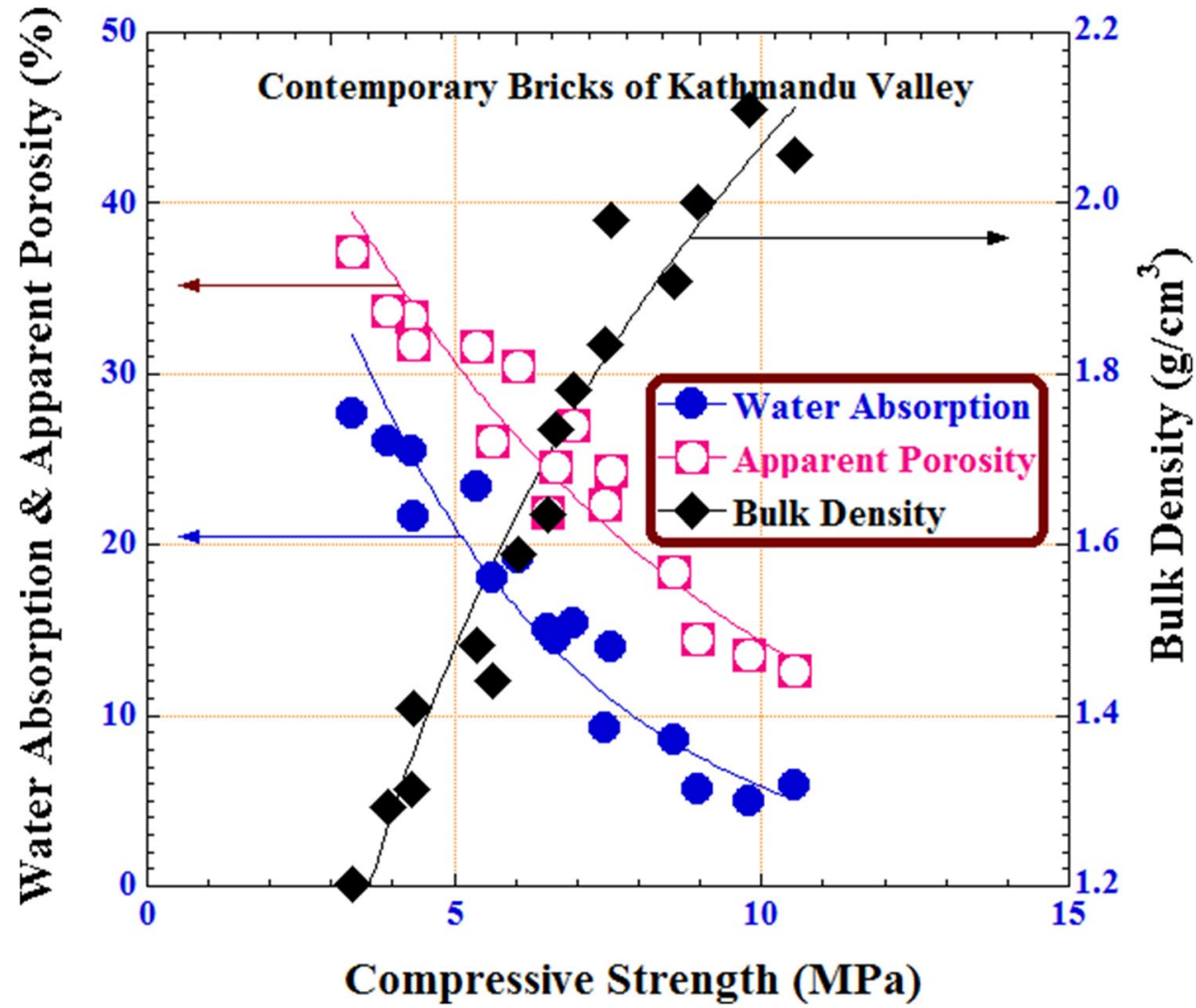

both the $W_{A C}$ and $P_{A}$ as shown in Figs. 8 and 9, respectively, although the $S_{C}$ of the brick samples is increased with increasing their $D_{B}$ (Fig. 10). The increase of the mechanical properties in terms of flexural and crushing strengths of floor and wall tiles were displayed the same trend of bulk density [54]. Consequently, to improve the mechanical properties of the clay brick bodies, efforts need to focus on decreasing both the $W_{A C}$ and $P_{A}$, and on increasing the $D_{B}$ as well, because these three most effective physico-sintering properties are responsible for the betterment of the mechanical properties of the fired-clay brick bodies.

Among analyzed seventeen types of brick samples of Kathmandu valley, about $35 \%$ samples with $4-15 \% \mathrm{~W}_{\mathrm{A}^{\prime}}$ 9-25\% $\mathrm{P}_{\mathrm{A}}, 7-11 \mathrm{MPa}_{\mathrm{C}}$ and more than $1.80 \mathrm{~g} / \mathrm{cm}^{3}$ bulk density (Fig. 11) can classify as II grade bricks, and the remaining samples can classify as III class bricks based on the IS standards [55]. The III class bricks can use as nonload bearing structures like boundary walls [46]. The raw material for brick fabrication is generally in a powder form and after its compaction into the desired shape, pores or void spaces might exist between the powder particles and such voids/pores could be eliminated by heat treatment at high temperature. However, it is often the case that such a void/pore elimination process in the ceramic bodies is incomplete and some residual porosity remains that affect the high water holding capacity and low bulk density as well.

Moreover, the voids/pores of the fired-clay bricks reported to be deterioration to the compressive strength, mostly due to two reasons that the void/pores reduce the cross-sectional area, across which a load applied, and they also act as stress concentrators as a result an applied tensile stress is amplified by a factor of 2 for an isolated spherical void/pore [56]. The influence of voids/pores of ceramic bodies on tensile strength was reported quite dramatic than $50 \%$ flexural strength was decreased by $10 \%$ volume porosity only [30]. Consequently, any residual voids/pores in the fired-clay brick samples have adverse effects on their compressive strength.

\section{Conclusions}

Mineralogical phases and some physico-mechanical properties (i.e., water absorption apparent porosity, bulk density, and compressive strength) of seventeen varieties of the modern clay brick samples collected from Kathmandu were studied for their quality assessments using ASTM criteria, XRPD and FTIR spectra analyses. The following conclusions are pointed out from the present results and discussion. 
1. The mineralogical phases present in the presently used fired-clay brick samples have mostly consisted of quartz, feldspars, spinel, primary mullite, and hematite including the muscovite type of mica mineral based on the results of XRPD and FTIR analyses.

2. The appearance of alumina-rich spinel peaks in some brick samples with the disappearance of feldspar peaks in XRPD patterns of the fired-brick indicated that they should be sintered between 900 and $1000^{\circ} \mathrm{C}$ and the disappearance of spinel peaks with the appearance of primary mullite phase noted that the sintering temperature of such clay bricks should be between 1000 and $1100^{\circ} \mathrm{C}$.

3. The compressive strength is exponentially increased with decreasing the water absorption capacity or apparent porosity and with increasing the bulk density of the clay bricks.

4. All the presently analyzed brick samples qualify as II and III class bricks whose physical and mechanical properties can be improved by employing various types of nano-siliceous materials to increase their quality and stability in the coming days.

5. Efforts need to focus on decreasing both the water holding capacity and the porosity with increasing density to upgrade the compressive strength. These properties of the analyzed bricks are primarily responsible for their betterment of quality and durability.

6. It is expected to be true that such research on the mineralogical compositions, physical and mechanical properties of the commercial bricks made in Nepal is heightening its development into a valuable material in improving the performance of stabilized bricks to increase its usage as a quality building materials.

7. In summary, the present findings of the mineralogical composition, physical and mechanical properties of the contemporary fired-clay brick products of Kathmandu valley could be established a valuable information for the formulation of a new one specific bricks in the future using available clay raw materials with small additions of low-cost waste materials for improving the brick performance at low production cost leading to a more durable, sustainable and economic construction.

Acknowledgements Research funding was provided by the University Grants Commission-Nepal (UGC-Nepal) under the UGC Faculty Research Grants-S\&T14-2072/073 scheme to JB and ND.

\section{Compliance with ethical standards}

Conflict of interest The authors declare that there are no conflicts of interest.

\section{References}

1. Fernandes FM, Lourenço PB, Castro F (2010) Ancient clay bricks: manufacture and properties. In: Dan MB, Přikryl R, Török A (eds) Materials, technologies and practice in historic heritage structures, Chapter-3. Springer, Dordrecht, pp 29-48. https://doi. org/10.1007/978-90-481-2684-2_3

2. Karhu M, Lagerbom J, Solismaa S, Honkanen M, Ismailov $A$, Räisänen ML, Huttunen-Saarivirta $E$, Levänen $E$, KivikytöReponen $P$ (2019) Mining tailings as raw materials for reaction-sintered aluminosilicate ceramics: effect of mineralogical composition on microstructure and properties. Ceram Int 45(4):4840-4848. https://doi.org/10.1016/j.ceram int.2018.11.180

3. Vijayaragavan R, Mullainathan S (2013) Study of raw materials for making ceramic product and physico-mechanical properties of ceramic product made from rock residue powder. Asian J Chem 25(suppl. issue):S449-S454

4. Cultrone G, Sebasti E, de la Torre MJ (2005) Mineralogical and physical behavior of solid bricks with additives. Constr Build Mater 19(1):39-48. https://doi.org/10.1016/j.conbuildma t.2004.04.035

5. Ajala AJ, Badarulzaman NA, Aramjat AB (2017) Impact of sintering temperatures on microstructure, porosity and mechanical strength of refractory brick. Mater Sci Forum 888:66-70. https ://doi.org/10.4028/www.scientific.net/MSF.888.66

6. Ajala AJ, Badarulzaman NA, Aramjat AB (2017) Influence of sintering temperatures on physico-mechanical properties and microstructure of refractory fireclay bricks. Int J Eng Technol 8(6):2588-2593. https://doi.org/10.21817/ijet/2016/v8i6/16080 6214

7. Rasmussen $\mathrm{KL}$, De La Fuente $\mathrm{GA}$, Bond $A D$, Mathiesen $\mathrm{KK}$, Vera SD (2012) Pottery firing temperatures: a new method for determining the firing temperature of ceramics and burnt clay. J Archaeol Sci 39(6):1705-1716. https://doi.org/10.1016/j. jas.2012.01.008

8. Johari I, Said S, Hisam B, Bakar A, Ahmad ZA (2010) Effect of the change of the firing temperature on microstructure and physical properties of clay bricks from Beruas (Malaysia). Sci Sinter 42(2):245-254. https://doi.org/10.2298/SOS1002245J

9. Dunham AC, McKnight AS, Warren I (2001) Mineral assemblages formed in Oxford clay fired under different time-temperature conditions with reference to brick manufacture. Proc Yorks Geol Soc 53(3):221-230. https://doi.org/10.1144/pygs.53.3.221

10. Karaman S, Ersahin S, Gunal H (2006) Firing temperature and firing time influence on mechanical physical properties of clay bricks. J Sci Indus Res 65(2):153-159

11. Ghorbel A, Fourati M, Bouaziz J (2008) Microstructural evolution and phase transformation of different sintered kaolin powder compacts. Mater Chem Phys 112(3):876-885. https:// doi.org/10.1016/j.matchemphys.2008.06.047

12. Braganca SR, Bergmann CP (2003) A view of whitewares mechanical strength and microstructure. Ceram Int 29(7):801806. https://doi.org/10.1016/S0272-8842(02)00234-1

13. Bordia RK, Camacho-Montes H (2012) Sintering: fundamentals and practice. In: Bansal NP, Boccaccini AR (eds) Ceramics and composites processing methods part-1: densification, 1 st edn. Wiley, USA, pp 3-42. https://doi.org/10.1002/9781118176665. ch1

14. Katsuki H, Kim J, Kim S-J, Kim J-Y, Pee J-H, Cho W-S (2016) Influence of alumina content in the raw clay on the sintering behavior of Karatsu ware. J Ceram Soc Jpn 124(8):833-837. https://doi. org/10.2109/jcersj2.16014

15. Bhattarai J, Okada K (1992) Characterization of clay raw materials in Nepal and their applicability for porcelain raw material. Clay 
Sci 8(6):393-402. https://doi.org/10.11362/jcssjclayscience1960 .8 .393

16. Njoya D, Tadjuidje FS, Ndzana EJA, Pountouonchi A, TessierDoyen N, Lecomte-Nana G (2017) Effect of flux content and heating rate on the microstructure and technological properties of Mayouom (Western-Cameroon) kaolinite clay based ceramics. J Asian Ceram Soc 5(4):422-426. https://doi.org/10.1016/j.jasce r.2017.09.004

17. Sokolar R, Kersnerovv L, Sveda M (2017) The effect of different fluxing agents on the sintering of dry pressed porcelain bodies. J Asian Ceram Soc 5(3):290-294. https://doi.org/10.1016/j.jasce r.2017.06.001

18. Sokolar R, Vodova L (2015) Sintering of feldspar rocks from Czech quarries. J Ceram Soc Jpn 123(1):62-67. https://doi.org/10.2109/ jcersj2.123.62

19. Maraveas $C$ (2020) Production of sustainable construction materials using agro-wastes. Materials 13(2):262. https://doi. org/10.3390/ma13020262

20. Kazmi SMS, Abbas S, Saleem MA, Munir MJ, Khitab A (2016) Manufacturing of sustainable clay bricks: utilization of waste sugarcane bagasse and rice husk ashes. Constr Build Mater 120:29-41. https://doi.org/10.1016/j.conbuildmat.2016.05.084

21. Munir MJ, Kazmi SMS, Wu YF, Hanif A, Khan MUA (2018) Thermally efficient fired clay bricks incorporating waste marble sludge: an industrial-scale study. J Clean Prod 174:1122-1135. https://doi.org/10.1016/j.jclepro.2017.11.060

22. Bilgin N, Yeprem HA, Arslan S, Bilgin A, Günay E, Maroglu M (2012) Use of waste marble powder in brick industry. Constr Build Mater 29:449-457. https://doi.org/10.1016/j.conbuildma t.2011.10.011

23. Kazmi SMS, Abbas S, Nehdi ML, Saleem MA, Munir MJ (2017) Feasibility of using waste glass sludge in production of ecofriendly clay bricks. J Mater Civ Eng 29(8):04017056. https://doi. org/10.1061/(ASCE)MT.1943-5533.0001928

24. Sutcu M, Erdogmus E, Gencel O, Gholampour A, Atan E, Ozbakkaloglu T (2019) Recycling of bottom ash and fly ash wastes in eco-friendly clay brick production. J Clean Prod 233:753-764. https://doi.org/10.1016/j.jclepro.2019.06.017

25. Abbas S, Saleem MA, Kazmi SMS, Munir MJ (2017) Production of sustainable clay bricks using waste fly ash: mechanical and durability properties. J Build Eng 14:7-14. https://doi.org/10.1016/j. jobe.2017.09.008

26. Aduda BO, Nyongesa FW (2000) Role of aspect ratio in elastic modulus-porosity relationship of triaxial porcelain. Br Ceram Trans 99(5):206-211. https://doi.org/10.1179/096797800680956

27. Grubesa IN, Vracevic M, Ranogajec J, Vucetic S (2020) Influence of pore-size distribution on the resistance of clay brick to freezethaw cycles. Materials 13:2364. https://doi.org/10.3390/ma131 02364

28. Coletti C, Culturone G, Maritan L, Mazzoli C (2016) Combined multi-analytical approach for study of pore system in bricks: How much porosity is there? Mater Charact 121:82-92. https:// doi.org/10.1016/j.matchar.2016.09.024

29. Dondi D, Marsigli M, Venturi L (1999) Microstructure and mechanical properties of clay bricks: comparison between fast firing and traditional firing. Br Ceram Trans 98(1):12-18. https:// doi.org/10.1179/096797899680183

30. Callister WD Jr (2010) Materials science and engineering. Willey, Hoboken, pp 451-453

31. Alves HJ, Melchiades FG, Boschi AO (2012) Effect of feldspar particle size on the porous microstructure and stain resistance of polished porcelain tiles. J Euro Ceram Soc 32(10):2095-2102. https://doi.org/10.1016/j.jeurceramsoc.2012.03.019

32. Martin-Marquez J, Rincon JM, Romero M (2010) Effect of microstructure on mechanical properties of porcelain stoneware. J
Eur Ceram Soc 30(15):3063-3069. https://doi.org/10.1016/j.jeurc eramsoc.2010.07.015

33. Budathoki P, Duwal N, Bhattarai J (2018) Investigation on the physico-sintering and mechanical properties of clay tiles available in Kathmandu valley of Nepal. Asian J Chem 30(11):25152520. https://doi.org/10.14233/ajchem.2018.21509

34. Budathoki B, Poudyal G, Oli RR, Duwal N, Bhattarai J (2018) Assessment on the characterization of mineralogical phase of ceramic tiles available in Kathmandu valley (Nepal) using XRD and FTIR analyses. Int J AppI Sci Biotechnol 6(3):238-243. https ://doi.org/10.3126/ijasbt.v6i3.21171

35. Ghale DB, Bohara NB, Duwal N, Bhattarai J (2019) Investigation on the mineralogical phase of ancient brick samples of Kathmandu valley (Nepal) using XRD and FTIR analysis. Rasayan J Chem 12(2):402-408. https://doi.org/10.31788/RJC.2019.12240 34

36. Bhattarai J, Ghale DB, Chapagain YP, Bohara NB, Duwal N (2018) Study on the physical and mechanical properties of ancient clay brick samples of Kathmandu valley, Nepal. Tribhuvan Univ J 32(2):1-18. https://doi.org/10.3126/tuj.v32i2.24699

37. Bohara NB, Ghale DB, Chapagain YP, Duwal N, Bhattarai J (2020) Effect of firing temperature on physico-mechanical properties of contemporary clay brick productions in Lalitpur (Nepal). Bangladesh J Sci Indus Res 55(1):43-52. https://doi.org/10.3329/bjsir .v55i1.46731

38. Bohara NB, Ghale DB, Bhat LB, Duwal N, Bhattarai J (2018) Investigation of the firing temperature effects on clay brick sample; part-I: mineralogical phase characterization. Bibechana 16:122130. https://doi.org/10.3126/bibechana.v16i0.21319

39. JCPDS (1999) Joint Committee on Powder Diffraction Standards

40. ASTM C20-00 (2015) Standard test methods for apparent porosity, water absorption, apparent specific gravity and bulk density of burned refractory brick and shapes by boiling water. In: Annual book of ASTM Standards, vol 15.01. ASTM International, West Conshohocken. https://doi.org/10.1520/C0020-00R15

41. ASTM C1424-15 (2015) Standard test methods for monotonic compressive strength of advanced ceramics at ambient temperature. In: Annual book of ASTM Standards, vol 15.01. ASTM International, West Conshohocken. https://doi.org/10.1520/ C1424-15

42. Sonuparlak B, Sarikaya M, Aksay IA (1987) Spinel phase formation during the $980^{\circ} \mathrm{C}$ exothermic reaction in the kaolinite-tomullite reaction series. J Am Ceram Soc 70(1):837-842. https:// doi.org/10.1111/j.1151-2916.1987.tb05637.x

43. Brindley B, Nakahira M (1959) The kaolinite-mullite reaction series-III: the high-temperature phases. J Am Ceram Soc 42(7):311-324. https://doi.org/10.1111/j.1151-2916.1959.tb143 $16 . x$

44. Madejova J (2003) FTIR techniques in clay mineral studies. Vib Spectrosc 31(1):1-10. https://doi.org/10.1016/S0924 -2031(02)00065-6

45. Farmer VC (2000) Transverse and longitudinal crystal modes associated with $\mathrm{OH}$ stretching vibrations in single crystals of kaolinite and dickite. Spectrochim Acta A 56(5):927-930. https ://doi.org/10.1016/S1386-1425(99)00182-1

46. Hossiney N, Das P, Krishna Mohan M, George J (2018) In-plant production of bricks containing waste foundry sand-a study with Belgaum foundry industry. Case Stud Constr Mater 9:e00170. https://doi.org/10.1016/j.cscm.2018.e00170

47. Adeniyi Fl, Ogundiran MB, Hemalatha T, Hanumantari BB (2020) Characterization of raw and thermally treated Nigerian kaolinite-containing clays using instrumental techniques. SN Appl Sci 2:821. https://doi.org/10.1007/s42452-020-2610-x

48. Alabarse FG, Conceicao RV, Balazaretti NM, Schento F, Xavier AM (2010) In-situ FTIR analyses of bentonite under high pressure. 
Appl Clay Sci 51(1/2):202-208. https://doi.org/10.1016/j. clay.2010.11.017

49. Cheng H, Liu Q, Yang J, Du X, Frost RL (2012) The thermal behavior of kaolinite intercalation complexes-a review. Thermochim Acta 545:1-13. https://doi.org/10.1016/j.tca.2012.04.005

50. Reig FB, Gemino-Adelantado JV, Moya Moreno MC (2002) FTIR quantitative analysis of calcium carbonate (calcite) and silica (quartz) mixtures using the constant ratio method: application to geological samples. Talanta 58(4):811-821. https://doi. org/10.1016/S0039-9140(02)00372-7

51. Hlavay J, Jonas K, Elek S, Inczedy J (1978) Characterization of the particle size and the crystallinity of certain minerals by IR spectrophotometry and other instrumental methods-II; Investigations on quartz and feldspar. Clays Clay Miner 26(2):139-143. https://doi.org/10.1346/CCMN.1978.0260209

52. Seco A, Urmeneta P, Prieto E, Marcelino S, Garcia B, Miquelez $L$ (2017) Estimated and real durability of unfired clay bricks: determining factors and representativeness of the laboratory tests. Constr Build Mater 131:600-605. https://doi.org/10.1016/j. conbuildmat.2016.11.107
53. Ojo EB, Mustapha K, Teixeira RS, Savastano H Jr (2019) Development of unfired earthen building materials using muscovite rich soils and alkali activator. Case Stud Constr Mater 11:e00262. https://doi.org/10.1016/j.cscm.2019.e00262

54. Darweesh HHM (2019) Recycling of glass waste in ceramicspart I: physical, mechanical and thermal properties. SN Appl Sci 1:1274. https://doi.org/10.1007/s42452-019-1304-8

55. IS 1077 (1992) Common burnt clay building brick specification. Bureau of Indian Standards, New Delhi, p 13

56. Coble RL, Kingery WD (1956) Effect of porosity on physical properties of sintered alumina. J Am Ceram Soc 39(11):377-385. https://doi.org/10.1111/j.1151-2916.1956.tb15608.x

Publisher's Note Springer Nature remains neutral with regard to jurisdictional claims in published maps and institutional affiliations. 